\title{
An Electrochemical Detection of Metallothioneins at the Zeptomole Level in Nanolitre Volumes
}

\author{
Vojtech Adam ${ }^{1,2}$, Jiri Baloun ${ }^{1}$, Ivo Fabrik ${ }^{1,3}$, Libuse Trnkova ${ }^{4}$ and Rene Kizek ${ }^{1, *}$ \\ ${ }^{1}$ Department of Chemistry and Biochemistry and ${ }^{2}$ Department of Animal Nutrition and Forage \\ Production, Faculty of Agronomy, Mendel University of Agriculture and Forestry, Zemedelska 1, \\ CZ-613 00 Brno, Czech Republic; E-mail: kizek@sci.muni.cz \\ ${ }^{3}$ Department of Biochemistry and ${ }^{4}$ Department of Chemistry, Faculty of Science, Masaryk \\ University, Kotlarska 2, CZ-611 37 Brno, Czech Republic
}

* Author to whom correspondence should be addressed; E-mail: kizek@sci.muni.cz

Received: 15 March 2008 / Accepted: 26 March 2008 / Published: 1 April 2008

\begin{abstract}
We report on improvement of the adsorptive transfer stripping technique (AdTS) coupled with the differential pulse voltammetry Brdicka reaction to determine a thiol-protein. The current technique has been unable to generate reproducible results when analyzing very low sample volumes (nanolitres). This obstacle can be overcome technically by modifying the current transfer technique including cooling step of the adsorbed analyte. We tested the technique on determination of a promising tumour disease marker protein called metallothionein (MT). The detection limit (3 S/N) of MT was evaluated as 500 zeptomoles per $500 \mathrm{~nL}(1 \mathrm{pM})$ and the quantification limit $(10 \mathrm{~S} / \mathrm{N})$ as 1,500 zeptomoles per $500 \mathrm{~nL}(3 \mathrm{pM})$. Further, the improved AdTS technique was utilized to analyze blood serum samples from patients with breast cancer. Based on the results obtained it can be concluded that the improved technique can be used to detect a thiolprotein in very low sample volumes and can also prevent interferences during the washing and transferring step.
\end{abstract}

Keywords: Proteomics, metallothionein, thiols, differential pulse voltammetry, Brdicka reaction, adsorptive transfer stripping technique, human blood serum, tumour disease, zeptomole 


\section{Introduction}

Thiols play a significant role in a number of biological activities; however, many of their functions still remain unclear. Their involvement with regulating reactive oxygen species and metal ions, as well as in transcription and translation have been and continue to be studied extensively. They could also serve as markers for many health problems $[1,2]$. Metallothioneins (MT) are a group of proteins rich in cysteine with molecular weights ranging from 6 to $10 \mathrm{kDa}$ [3-5]. These proteins' main physiological role is to maintain heavy metal ion homeostasis. MT's biological function is possibly associated with their overexpression in patients with a tumour disease [6-9]. Several papers have discussed and investigated the detection of metallothioneins using different methods [10-18]. These approaches utilized capillary electrophoresis, liquid chromatography mass spectrometry, inductive coupled plasma mass spectrometry, immunoassays and electrochemistry. Electrochemical techniques represent an alternative to hyphenated and high cost techniques due to their sensitivity and low cost $[17,18]$. The aim of this paper is to improve the current adsorptive transfer stripping technique (AdTS) to analyze MT in volumes down to nanolitres.

\section{Experimental}

\subsection{Chemicals, $p H$ measurements and pipetting}

Rabbit liver MT (MW 7143), containing $5.9 \% \mathrm{Cd}$ and $0.5 \% \mathrm{Zn}$, were purchased from Sigma Aldrich (St. Louis, USA). Tris(2-carboxyethyl)phosphine (TCEP) was prepared by Molecular Probes (Eugene, Oregon, USA). $10 \mu \mathrm{g} / \mathrm{mL}$ MT stock standard solutions were prepared with ACS grade water (Sigma-Aldrich, USA) and stored in the dark at $-20{ }^{\circ} \mathrm{C}$. Working standard solutions were prepared daily by dilution of the stock solutions. The $\mathrm{pH}$ value was measured using WTW inoLab Level 3 (Weilheim, Germany), connected to a computer and controlled by MultiLab Pilot software (Weilheim, Germany). The pH-electrode (SenTix-H, pH 0-14/3M KCl) was regularly calibrated by a set of WTW buffers ( $\mathrm{pH}$ 4.01, 7.00 and 10.00) (Weilheim, Germany). To pipette volumes down to micro and nanolitres, pipettes used were purchased from Eppendorf Research (Eppendorf, Germany) with the highest certified deviation $( \pm 12 \%)$.

\subsection{Electrochemical measurements}

Electrochemical measurements were performed with an AUTOLAB Analyser (EcoChemie, Netherlands) connected to a VA-Stand 663 (Metrohm, Switzerland), using a standard cell and three electrodes. The working electrode was a hanging mercury drop electrode (HMDE). The reference electrode was a $\mathrm{Ag} / \mathrm{AgCl} / 3 \mathrm{M} \mathrm{KCl}$ electrode and a glassy carbon electrode was used as the auxiliary electrode. Smoothing and baseline correction was employed by GPES 4.4 software supplied by EcoChemie. 
Adsorptive transfer stripping technique. The principle of the adsorptive transfer stripping technique is based on the strong adsorption of the target molecule on the surface of the working electrode at an open circuit (Fig. 1A). The hanging mercury drop electrode is periodically renewed (Figure 1A1). Target molecules are adsorbed on the surface of the renewed working electrode at an open circuit (Figure 1A2). The electrode is washed with a supporting electrolyte (Figure 1A3). The electrode with the adsorbed target molecules is measured in the presence of the supporting electrolyte (Figure 1A4).

Brdicka reaction of MT. MT was measured by AdTS coupled with a differential pulse voltammetry (DPV) Brdicka reaction. Brdicka supporting electrolyte $\left(1 \mathrm{mM} \mathrm{Co}\left(\mathrm{NH}_{3}\right)_{6} \mathrm{Cl}_{3}\right.$ and $1 \mathrm{M}$ ammonia buffer $\left(\mathrm{NH}_{3}(\mathrm{aq})+\mathrm{NH}_{4} \mathrm{Cl}, \mathrm{pH}=9.6\right)$ was used without surface-active agent additives. AdTS DPV Brdicka reaction parameters were as follows: an initial potential of $-0.35 \mathrm{~V}$, an end potential of $-1.8 \mathrm{~V}$, a modulation time of $0.057 \mathrm{~s}$, a time interval of $0.2 \mathrm{~s}$, a step potential of $1.05 \mathrm{mV}$, a modulation amplitude of $250 \mathrm{mV}, \mathrm{E}_{\mathrm{ads}}=0 \mathrm{~V}$. Temperature of supporting electrolyte was $4{ }^{\circ} \mathrm{C}$.

Figure 1. Scheme of adsorptive transfer technique (A). Typical voltammograms of 100 nM MT (solid red line), supporting electrolyte (dotted black line) (B).

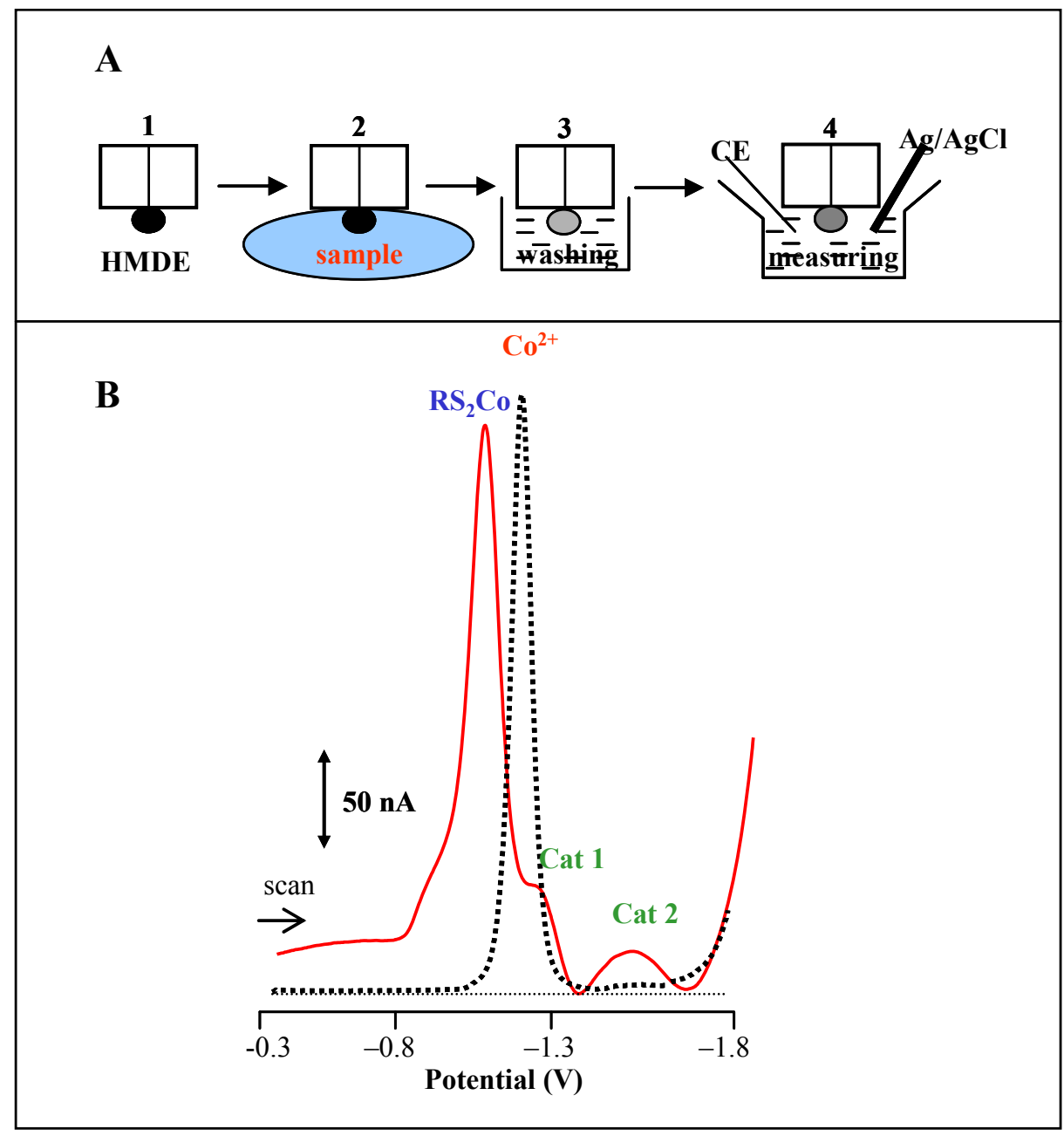




\subsection{Clinical material}

Human blood serum samples from patients with breast cancer were obtained from the Department of Clinical Biochemistry and Pathobiochemistry, FN Motol, Prague, Czech Republic. The sampled sera were immediately frozen at $-20{ }^{\circ} \mathrm{C}$ prior to their preparation. The sample was prepared by heat treatment followed by solvent precipitation. The samples were kept at $99{ }^{\circ} \mathrm{C}$ in a thermomixer (Eppendorf 5430, USA) for $15 \mathrm{~min}$. with occasional stirring, and then cooled to $4{ }^{\circ} \mathrm{C}$. The denatured homogenates were centrifuged at $4{ }^{\circ} \mathrm{C}, 15,000 \mathrm{~g}$ for $30 \mathrm{~min}$. (Eppendorf 5402, USA). Heat treatment and solvent precipitation effectively denatured and removed high molecular weight proteins from the samples [19]. MT levels in the human blood serum samples were measured by AdTS DPV Brdicka reaction.

\subsection{Descriptive statistics}

Microsoft Excel ${ }^{\circledR}$ (USA) was used for mathematical analyses. Results are expressed as mean \pm S.D. unless noted otherwise. The detection limits $(3 \mathrm{~S} / \mathrm{N})$ were calculated according to Long [20], whereas $\mathrm{N}$ was expressed as standard deviation of noise determined in the signal domain.

\section{Results and Discussion}

Proteomic research demands highly sensitive analytical instruments to detect very low volumes or amounts of a biological sample. Analysis is preferably carried out on the instruments to be low cost and easy to use, and, moreover, there is great demand on miniaturization of the instruments used [2136]. The impact of these demands is well demonstrated in the field of flow microchips technology [3752]. Electrochemical devices, methods and approaches have a valuable contribution to this field. In particular, the introduction of adsorptive transfer technique by Prof. Palecek was a great advancement in the electroanalysis of low volume samples [52-58].

\subsection{Utilizing of adsorptive transfer technique for analysis of MT}

The AdTS technique coupled with the DPV Brdicka reaction can be used to detect metallothionein in low sample volumes and can also prevent interferences during the washing and transferring step (Figure 1A,B). The technique, however, has its limitations. This technique currently is unable to generate reproducible results when analyzing very low sample volumes. We attempted to investigate how changes in drop volume and area of the working electrode influence the repeatability and sensitivity of the measurements. Study of MT $(100 \mu \mathrm{M})$ drop volumes of 2.5, 5.0, 10 and $15 \mu \mathrm{L}$ by AdTS DPV Brdicka reaction at HMDE with a drop area of $400 \mu \mathrm{m}^{2}$, resulted in well developed and reproducible Brdicka catalytic signals of 1.5, 3.0, 6.2 and 9.2 ng of MT, respectively (Figure 2Aa). The height of the Cat2 signal was nearly proportional to MT content with a $\mathrm{R}^{2}$ value of 0.9816 . The measurements were repeated five times and relative standard deviation of Cat 2 peak height did not exceed $5 \%$. 
MT measurements $(100 \mathrm{nM})$ with drop volumes of $0.5,1.0,1.5,2.5$ and $5.0 \mu \mathrm{L}$ could be carried out using HMDE with a drop area of $250 \mu \mathrm{m}^{2}$. The Brdicka catalytic peaks were well apparent in the measured voltammograms, whereas Cat 2 peaks were sufficiently detected even at low MT amounts of 0.3, 0.6, 0.9, 1.5 and $3.0 \mathrm{ng}$ (Figure 2Ba). However, relative standard deviation (R.S.D., \%) increased significantly with decreasing drop volume. The R.S.D. measurements of MT in 2.5, 1.5, 1.0 and $0.5 \mu \mathrm{L}$ were $4 \%, 8 \%, 15 \%$ and $40 \%$, respectively. Enhanced Cat 2 peak height was observed with increasing R.S.D. The Cat2 peak measured after adsorption of MT from drop of $500 \mathrm{~nL}$ was five times higher compared to that measured after adsorption of MT from drop of 2,500 $\mathrm{nL}$. The enhanced Cat2 peak height was almost proportional to the decrease in drop volume (Figure 2Ba). This phenomenon is possibly due to water evaporation from a drop of MT standard solution. Due to this phenomenon, MT concentration increased and a higher peak was observed. Based on the results obtained, this approach cannot be used for quantitative determination of proteins in very low sample volumes at room temperature.

Figure 2. Dependence of Cat2 peak height of MT on drop volumes of 2.5, 5.0, 10 and 15 $\mu \mathrm{L}$ (A, non-cooled parafilm $\mathbf{a}$ and cooled parafilm $\mathbf{b}$, measured at HMDE of area of 400 $\left.\mu \mathrm{m}^{2}\right)$ and of $0.5,1,1.5,2.5$ and $5 \mu \mathrm{L}(\mathbf{B}$, non-cooled parafilm a and cooled parafilm $\mathbf{b}$, measured at HMDE of area of $\left.250 \mu \mathrm{m}^{2}\right)$. In insets: typical DP voltammograms of MT $(100 \mathrm{nM})$. Peak height of $72.3 \mathrm{nA}(\mathrm{Aa}), 78.6 \mathrm{nA}(\mathrm{Ab}), 1.1 \mathrm{nA}(\mathrm{Ba})$ and $22.3(\mathrm{Bb})$ correspond to $100 \%$.

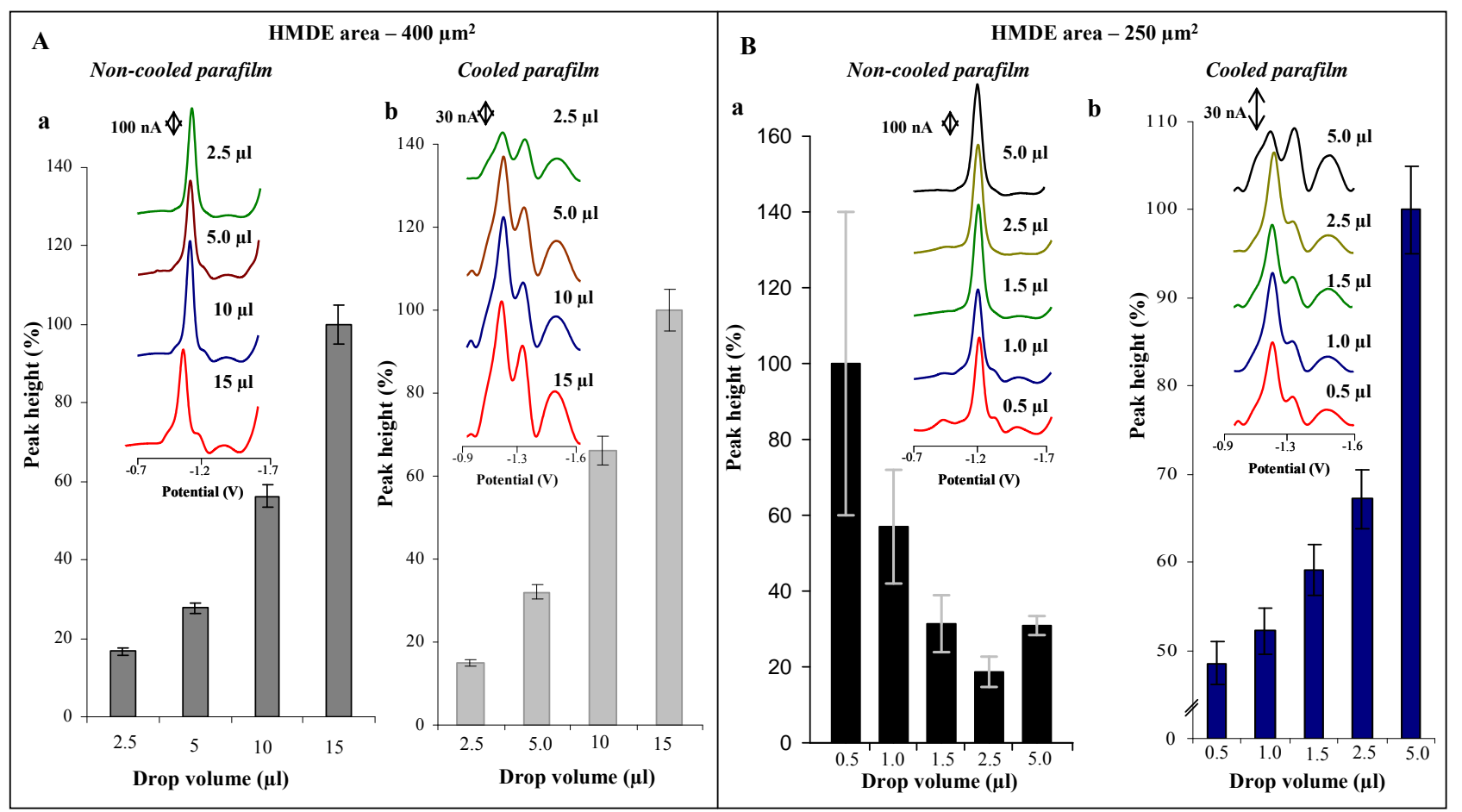

\subsection{Improvement of the adsorptive transfer technique}

This obstacle can be overcome by technically modifying the current transfer technique. A small square of parafilm $(10 \times 10 \mathrm{~cm}$, Sigma-Aldrich) is seamed on a microscope slide by a burner (Figure 
3a). The slide is washed with ethanol and distilled water (Milli Q, $18 \mathrm{M} \Omega$ ) and transferred to a cooled space, in this case to a beaker filled with distilled water and placed in a tempered water bath (Julabo, Germany, Figure $3 b$ ) at a temperature of $2{ }^{\circ} \mathrm{C}$. Prior to use, the slide is removed from the bath and dried using cellulose. MT low volume drops were pipetted onto the dried slide (Figure 3c) and then adsorbed on the surface of HMDE at open circuit (Figure 3d). The electrode with the adsorbed target molecule is washed and measured (Figures 3e-g). The experiment discussed in Section 3.1. was repeated and MT measurements $(100 \mu \mathrm{M})$ with drop volumes of 2.5, 5.0, 10 and $15 \mu \mathrm{L}$ were carried out using the improved AdTS DPV Brdicka reaction and HMDE with a drop area of $400 \mu \mathrm{m}^{2}$ (Fig. $2 \mathrm{Ab}$ ). Compared to results shown in Fig. 2Aa the signals were higher and more proportional to MT content with a $\mathrm{R}^{2}$ value of 1.000 . Relative standard deviation of Cat2 $(n=5)$ peak height did not exceed $4 \%$.

\subsection{Electrochemical analysis of MT in low volume samples}

Due to these results further studies were done on MT samples with various volumes. Investigations were done on MT containing samples $(100 \mathrm{nM})$ with volumes of $0.5,1.0,1.5,2.5$ and $5.0 \mu \mathrm{L}$ using HMDE with a drop area of $250 \mu \mathrm{m}^{2}$ (Figure 2Bb). The improvement of the transfer technique described above enabled us to detect MT in very low volume samples in comparison to the "standard" transfer technique (Figure 2Ba,b). The height of Cat2 signal was proportional to MT content with a $\mathrm{R}^{2}$ value of 0.9928 and the relative standard deviation of Cat2 peak height was not higher than $6 \%$. Substantial improvement in results was due to decrease in water evaporation in low volume drops.

Figure 3. Scheme of improvement of the transfer to detect MT in very low volumes of a sample. Microscopic slide, degreasing and seaming of small square from parafilm $(10 \times$ $10 \mathrm{~cm}$, Sigma-Aldrich) (a), transferring it to a beaker filled with distilled water and placed in the tempered water bath (temperature of $2{ }^{\circ} \mathrm{C}$, at least 15 min., Julabo, Germany) (b), drying it using cellulose and pipetting of a sample on it (c), adsorbing of MT on the surface of HMDE (d), transferring the electrode (e) and washing it with supporting electrolyte (f), transferring the electrode and measuring (g).

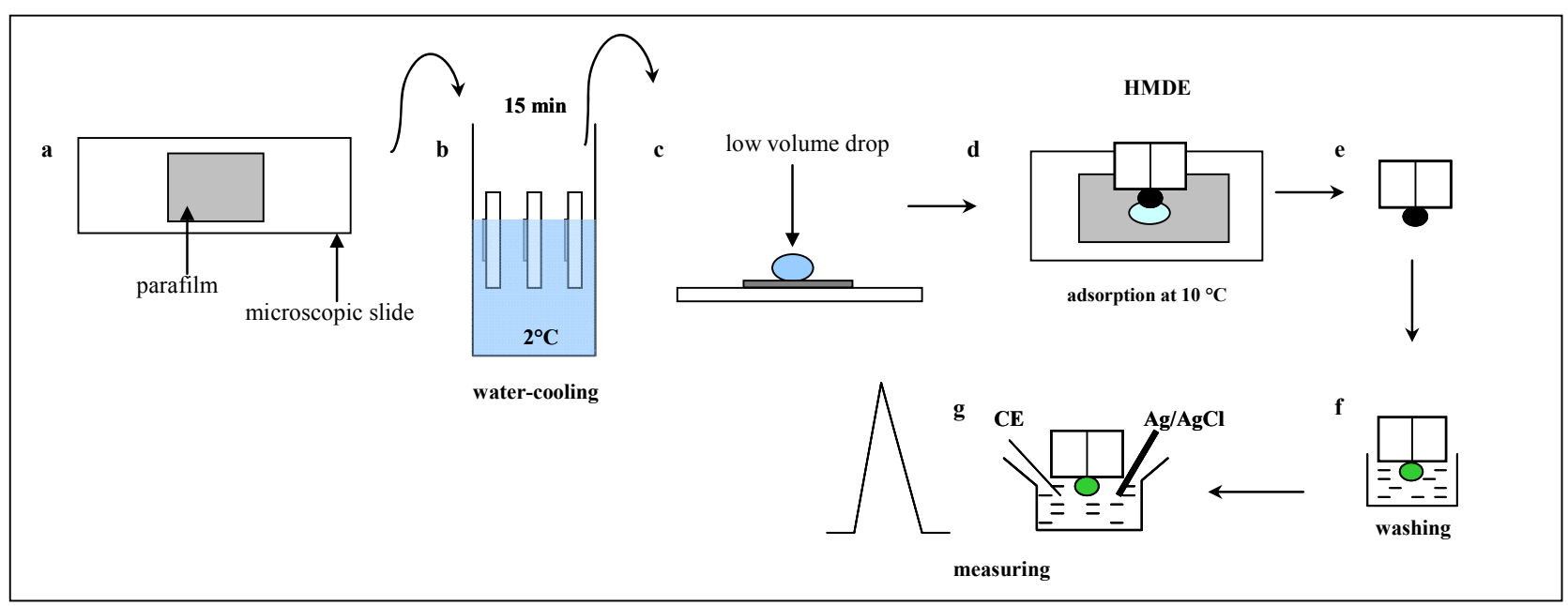


Additional investigations on the influence of the accumulation of MT over time $(500 \mathrm{~nL})$ on Cat2 peak height were studied. The peak enhanced to $120 \mathrm{~s}$ long accumulation, then gradually decreased (Figure 4A).

Figure 4. Dependence of Cat2 peak height on accumulation time (A) and on MT concentration within the range from 25 to $5,000 \mathrm{pM}$ (blue square, B) and from 25 to 500 pM (red triangles, in inset in B). Dependence of Cat2 peak potential on MT concentration (black dot, B). Volume: $500 \mathrm{~nL}$, HMDE area: $250 \mu \mathrm{m}^{2}$. Other experimental conditions the same as in Figure 1 and 3.

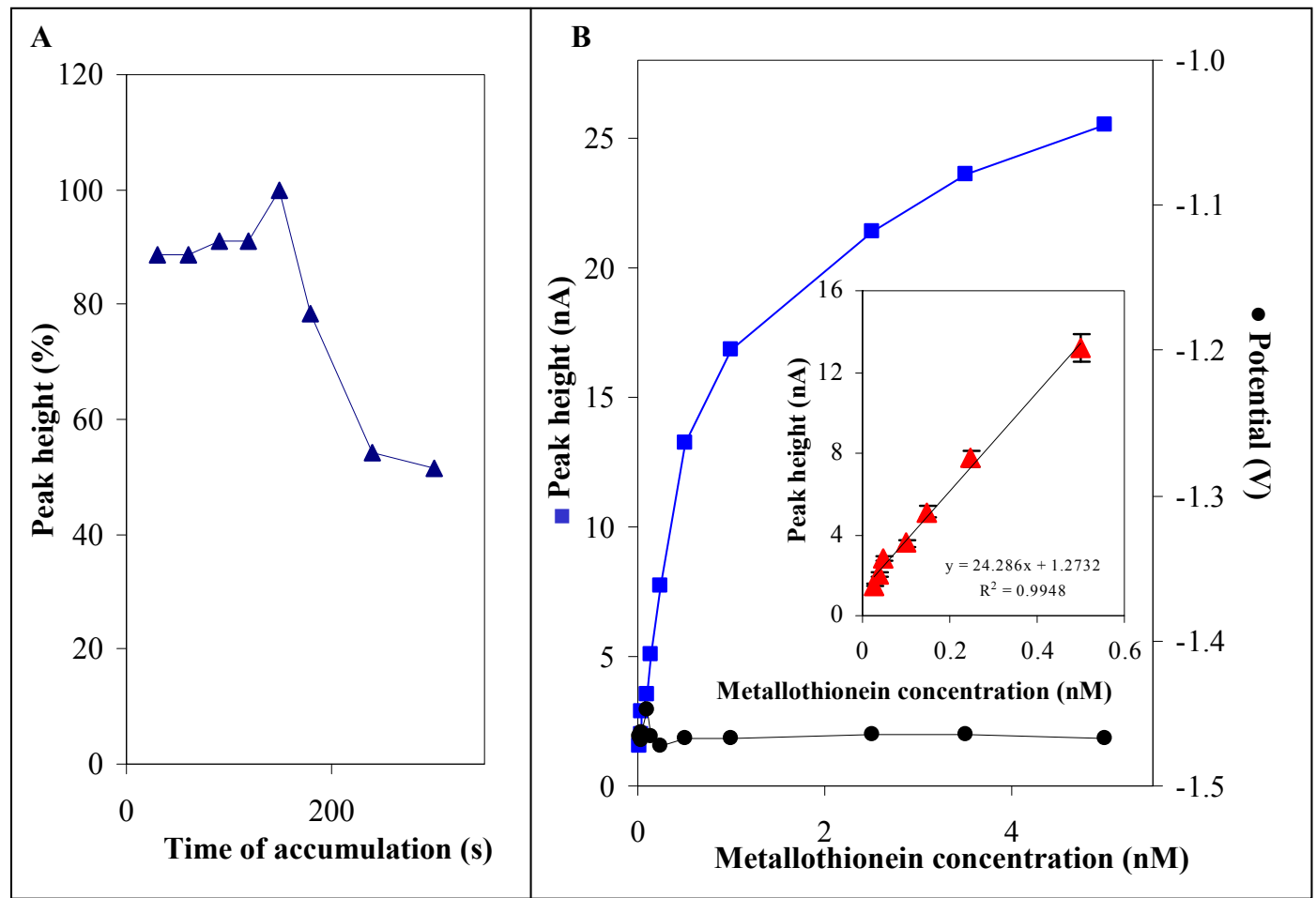

Under $120 \mathrm{~s}$ long accumulation of MT on the surface of HMDE we measured the dependence of Cat 2 peak height on MT concentration. The peak height increased with increasing MT concentration within the tested interval from 25 to $5,000 \mathrm{nM}$ (Fig. 4B). The linear dependence was measured within the interval from 25 to $500 \mathrm{pM}$ with relative standard deviation of $2.5 \%(\mathrm{n}=5$, inset in Figure 4B). Measurements were repeatable within a day and also weeks later. The relative deviation of such measurements did not exceed $5 \%(\mathrm{n}=4)$. The detection limit $(3 \mathrm{~S} / \mathrm{N})$ of MT was evaluated as 500 zeptomoles per $500 \mathrm{~nL}(1 \mathrm{pM})$ and the quantification limit $(10 \mathrm{~S} / \mathrm{N})$ as 1,500 zeptomoles per $500 \mathrm{nl}(3$ $\mathrm{pM})$.

\subsection{Analysis of blood serum from patients with a tumour disease}

Recently published studies have shown an association between metallothionein and breast cancer. MT level analysis of one hundred patients with this type of cancer was reported. The authors showed a correlation between high levels of MT and an increase in disease prognosis and vice versa [59]. Using a different approach than the latter, we attempted to utilize the improved transfer technique mentioned above for measuring MT in blood serum from patients with breast cancer. MT samples with $500 \mathrm{~nL}$ 
volumes were analyzed using the revised technique according to the scheme shown in Fig. 3 and MT samples with $5 \mu \mathrm{L}$ volumes were analyzed using the "standard" technique. Results from the revised technique were compared with the "standard" transfer technique data. In both cases well developed catalytic signals were observed (Figure 5).

Figure 5. DP voltammograms of human blood serum samples from four patients with breast cancer. Volume of the sample analyzed: $500 \mathrm{nl}$, HMDE area: $250 \mu \mathrm{m}^{2}$. Other experimental conditions the same as in Figure 1 and 3.

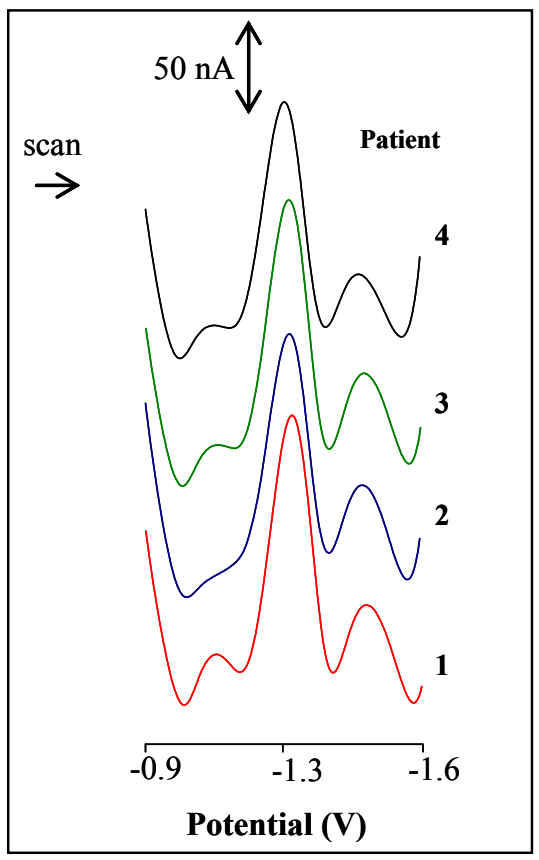

Quantification of MT levels in the samples was based on the determination of the Cat2 peak height. MT levels varied from 0.8 to $2.4 \mu \mathrm{M}(1.56 \pm 0.79 \mu \mathrm{M})$ in respect to $5 \mu \mathrm{L}$ volumes and from 1.2 to 1.7 $\mu \mathrm{M}(1.46 \pm 0.28 \mu \mathrm{M})$ in respect to $500 \mathrm{~nL}$ volumes. A significant difference in standard deviations was observed between the two techniques. A sample prepared according to the procedure mentioned in the "Experimental" section contained several low molecular weight thiols (e.g. glutathione) in addition to the presence of MT containing thiols. This phenomenon could be a result due to altered adsorption of these substances at a lower temperature and lower sample volume. However, the means of MT levels determined in breast cancer patients by both techniques were in good agreement with each other.

\section{Conclusions}

Proteomic approaches to the identification of novel biomarkers for cancer diagnosis and staging have traditionally relied on the identification of differentially expressed proteins between tumour cells and their normal counterparts based on the patterns of protein expression observed by two-dimensional gel electrophoresis (2D-PAGE) and mass spectrometry. Here, we report on alternative way to detect proteins that can be carried out with very low demands on an instrument, consumable costs and of operator skill. The present paper suggested a simple but effective improvement (cooling of the 
parafilm) to the adsorptive transfer technique, which consequently resulted in several advantages when conducting measurements. Diminished water evaporation in low volume drops and greater MT adsorption under improved controlled conditions were the major changes observed which allowed measurements down to several hundred nanolitres with relatively low standard deviations and low detection and quantification limit.

\section{Acknowledgements}

The authors wish to express their thanks to Dr. Jiri Kukacka for providing clinical samples and to Dr. Grace J. Chavis for language corrections and discussions. Financial support from the Grant Agency of the Czech Academy of Sciences (Grant No. GAAV IAAA40199071) is greatly acknowledged.

\section{References}

1. Fredriksson, S.; Dixon, W.; Ji, H.; Koong, A.C.; Mindrinos, M.; Davis, R.W. Multiplexed protein detection by proximity ligation for cancer biomarker validation. Nat. Methods 2007, 4, 327-329.

2. Bertolini, F.; Shaked, Y.; Mancuso, P.; Kerbel, R.S. The multifaceted circulating endothelial cell in cancer: towards marker and target identification. Nat. Rev. Cancer 2006, 6, 833-845.

3. Kagi, J.H.R. Overview of Metallothionein. Method Enzymol. 1991, 205, 613-626.

4. Kagi, J.H.R.; Schaffer, A. Biochemistry of Metallothionein. Biochemistry 1988, 27, 8509-8515.

5. Hamer, D.H. Metallothionein. Annu. Rev. Biochem. 1986, 55, 913-951.

6. Angel, P.; Karin, M. The Role of Jun, Fos and the Ap-1 Complex in Cell-Proliferation and Transformation. Biochim. Biophys. Acta 1991, 1072, 129-157.

7. Lee, W.; Haslinger, A.; Karin, M.; Tjian, R. Activation of Transcription by 2 Factors That Bind Promoter and Enhancer Sequences of the Human Metallothionein Gene and Sv40. Nature 1987, 325, 368-372.

8. Karin, M.; Haslinger, A.; Holtgreve, H.; Richards, R.I.; Krauter, P.; Westphal, H.M.; Beato, M. Characterization of DNA-Sequences through Which Cadmium and Glucocorticoid Hormones Induce Human Metallothionein-Iia Gene. Nature 1984, 308, 513-519.

9. Palmiter, R.D.; Norstedt, G.; Gelinas, R.E.; Hammer, R.E.; Brinster, R.L. Metallothionein Human Gh Fusion Genes Stimulate Growth of Mice. Science 1983, 222, 809-814.

10. Szpunar, J. Advances in analytical methodology for bioinorganic speciation analysis: metallomics, metalloproteomics and heteroatom-tagged proteomics and metabolomics. Analyst 2005, 130, 442-465.

11. Wolf, C.; Schaumloffel, D.; Richarz, A.N.; Prange, A.; Bratter, P. CZE-ICP-MS separation of metallothioneins in human brain cytosols: comparability of electropherograms obtained from different sample matrices. Analyst 2003, 128, 576-580.

12. Szpunar, J. Bio-inorganic speciation analysis by hyphenated techniques. Analyst 2000, 125, 963 988. 
13. Szpunar, J. Trace element speciation analysis of biomaterials by high-performance liquid chromatography with inductively coupled plasma mass spectrometric detection. Trac-Trends Anal. Chem. 2000, 19, 127-137.

14. Ferrarello, C.N.; de la Campa, M.D.F.; Carrasco, J.F.; Sanz-Medel, A. Speciation of metallothionein-like proteins of the mussel Mytilus edulis at basal levels by chromatographic separations coupled to quadrupole and double-focusing magnetic sector ICPMS. Anal. Chem. 2000, 72, 5874-5880.

15. Harrington, C.F.; Vidler, D.S.; Watts, M.J.; Hall, J.F. Potential for using isotopically altered metalloproteins in species-specific isotope dilution analysis of proteins by HPLC coupled to inductively coupled plasma mass spectrometry. Anal. Chem. 2005, 77, 4034-4041.

16. Wang, Z.X.; Prange, A. Use of surface-modified capillaries in the separation and characterization of metallothionein isoforms by capillary electrophoresis inductively coupled plasma mass spectrometry. Anal. Chem. 2002, 74, 626-631.

17. Kizek, R.; Trnkova, L.; Palecek, E. Determination of metallothionein at the femtomole level by constant current stripping chronopotentiometry. Anal. Chem. 2001, 73, 4801-4807.

18. Luo, D.B.; Lan, J.G.; Zhou, C.; Luo, C.X. Polarographic behavior of Co(II)-BSA or -HSA complex in the presence of a guanidine modifier. Anal. Chem. 2003, 75, 6346-6350.

19. Erk, M.; Ivankovic, D.; Raspor, B.; Pavicic, J. Evaluation of different purification procedures for the electrochemical quantification of mussel metallothioneins. Talanta 2002, 57, 1211-1218.

20. Long, G.L.; Winefordner, J.D. Limit of Detection. Anal. Chem. 1983, 55, A712-A724.

21. Adam, V.; Hanustiak, P.; Krizkova, S.; Beklova, M.; Zehnalek, J.; Trnkova, L.; Horna, A.; Sures, B.; Kizek, R. Palladium biosensor. Electroanalysis 2007, 19, 1909-1914.

22. Adam, V.; Krizkova, S.; Zitka, O.; Trnkova, L.; Petrlova, J.; Beklova, M.; Kizek, R. Determination of apo-metallothionein using adsorptive transfer stripping technique in connection with differential pulse voltammetry. Electroanalysis 2007, 19, 339-347.

23. Hubalek, J.; Hradecky, J.; Adam, V.; Krystofova, O.; Huska, D.; Masarik, M.; Trnkova, L.; Horna, A.; Klosova, K.; Adamek, M.; Zehnalek, J.; Kizek, R. Spectrometric and voltammetric analysis of urease - nickel nanoelectrode as an electrochemical sensor. Sensors 2007, 7, 12381255.

24. Huska, D.; Zitka, O.; Adam, V.; Beklova, M.; Krizkova, S.; Zeman, L.; Horna, A.; Havel, L.; Zehnalek, J.; Kizek, R. A sensor for investigating the interaction between biologically important heavy metals and glutathione. Czech J. Anim. Sci. 2007, 52, 37-43.

25. Krizkova, S.; Adam, V.; Petrlova, J.; Zitka, O.; Stejskal, K.; Zehnalek, J.; Sures, B.; Trnkova, L.; Beklova, M.; Kizek, R. A suggestion of electrochemical biosensor for study of platinum(II)DNA interactions. Electroanalysis 2007, 19, 331-338.

26. Petrek, J.; Havel, L.; Petrlova, J.; Adam, V.; Potesil, D.; Babula, P.; Kizek, R. Analysis of salicylic acid in willow barks and branches by an electrochemical method. Russ. J. Plant Physiol. 2007, 54, 553-558.

27. Petrlova, J.; Krizkova, S.; Zitka, O.; Hubalek, J.; Prusa, R.; Adam, V.; Wang, J.; Beklova, M.; Sures, B.; Kizek, R. Utilizing a chronopotentiometric sensor technique for metallothionein determination in fish tissues and their host parasites. Sens. Actuator B-Chem. 2007, 127, 112 119. 
28. Petrlova, J.; Masarik, M.; Potesil, D.; Adam, V.; Trnkova, L.; Kizek, R. Zeptomole detection of streptavidin using carbon paste electrode and square-wave voltammetry. Electroanalysis 2007, 19, 1177-1182.

29. Supalkova, V.; Petrek, J.; Havel, L.; Krizkova, S.; Petrlova, J.; Adam, V.; Potesil, D.; Babula, P.; Beklova, M.; Horna, A.; Kizek, R. Electrochemical sensors for detection of acetylsalicylic acid. Sensors 2006, 6, 1483-1497.

30. Vitecek, J.; Petrlova, J.; Petrek, J.; Adam, V.; Potesil, D.; Havel, L.; Mikelova, R.; Trnkova, L.; Kizek, R. Electrochemical study of S-nitrosoglutathione and nitric oxide by carbon fibre NO sensor and cyclic voltammetry - possible way of monitoring of nitric oxide. Electrochim. Acta 2006, 51, 5087-5094.

31. Adam, V.; Petrlova, J.; Potesil, D.; Lubal, P.; Zehnalek, J.; Sures, B.; Kizek, R. New electrochemical biosensor to determine platinum cytostatics to DNA structure. Chem. Listy 2005, 99, 353-393.

32. Adam, V.; Petrlova, J.; Potesil, D.; Zehnalek, J.; Sures, B.; Trnkova, L.; Jelen, F.; Kizek, R. Study of metallothionein modified electrode surface behavior in the presence of heavy metal ions-biosensor. Electroanalysis 2005, 17, 1649-1657.

33. Adam, V.; Zehnalek, J.; Petrlova, J.; Potesil, D.; Sures, B.; Trnkova, L.; Jelen, F.; Vitecek, J.; Kizek, R. Phytochelatin modified electrode surface as a sensitive heavy-metal ion biosensor. Sensors 2005, 5, 70-84.

34. Petrlova, J.; Potesil, D.; Zehnalek, J.; Sures, B.; Adam, V.; Trnkova, L.; Kizek, R. Cisplatin electrochemical biosensor. Electrochim. Acta 2006, 51, 5169-5173.

35. Potesil, D.; Mikelova, R.; Adam, V.; Kizek, R.; Prusa, R. Change of the protein p53 electrochemical signal according to its structural form - Quick and sensitive distinguishing of native, denatured, and aggregated form of the "guardian of the genome". Protein J. 2006, 25, 23 32.

36. Trnkova, L.; Jelen, F.; Petrlova, J.; Adam, V.; Potesil, D.; Kizek, R. Elimination voltammetry with linear scan as a new detection method for DNA sensors. Sensors 2005, 5, 448-464.

37. Li, L.; Boedicker, J.Q.; Ismagilov, R.F. Using a multijunction microfluidic device to inject substrate into an array of preformed plugs without cross-contamination: Comparing theory and experiments. Anal. Chem. 2007, 79, 2756-2761.

38. Henares, T.G.; Takaishi, M.; Yoshida, N.; Terabe, S.; Mizutani, F.; Sekizawa, R.; Hisamoto, H. Integration of multianalyte sensing functions on a capillary-assembled microchip: Simultaneous determination of ion concentrations and enzymatic activities by a "drop-and-sip" technique. Anal. Chem. 2007, 79, 908-915.

39. Du, W.B.; Fang, Q.; Fang, Z.L. Microfluidic sequential injection analysis in a short capillary. Anal. Chem. 2006, 78, 6404-6410.

40. Lorenz, R.M.; Edgar, J.S.; Jeffries, G.D.M.; Chiu, D.T. Microfluidic and optical systems for the on-demand generation and manipulation of single femtoliter-volume aqueous droplets. Anal. Chem. 2006, 78, 6433-6439.

41. Legendre, L.A.; Bienvenue, J.M.; Roper, M.G.; Ferrance, J.P.; Landers, J.P. A simple, valveless microfluidic sample preparation device for extraction and amplification of DNA from nanolitervolume samples. Anal. Chem. 2006, 78, 1444-1451. 
42. Adam, V.; Zitka, O.; Dolezal, P.; Zeman, L.; Horna, A.; Hubalek, J.; Sileny, J.; Krizkova, S.; Trnkova, L.; Kizek, R. Lactoferrin isolation using monolithic column coupled with spectrometric or micro-amperometric detector. Sensors 2008, 8, 464-487.

43. Babula, P.; Huska, D.; Hanustiak, P.; Baloun, J.; Krizkova, S.; Adam, V.; Hubalek, J.; Havel, L.; Zemlicka, M.; Horna, A.; Beklova, M.; Kizek, R. Flow injection analysis coupled with carbon electrodes as the tool for analysis of naphthoquinones with respect to their content and functions in biological samples. Sensors 2006, 6, 1466-1482.

44. Prasek, J.; Adamek, M.; Hubalek, J.; Adam, V.; Trnkova, L.; Kizek, R. New hydrodynamic electrochemical arrangement for cadmium ions detection using thick-film chemical sensor electrodes. Sensors 2006, 6, 1498-1512.

45. Zitka, O.; Horna, A.; Stejskal, K.; Zehnalek, J.; Adam, V.; Havel, L.; Zeman, L.; Kizek, R. Study of structural changes of lactoferrin using flow injection analysis with electrochemical detection on glassy carbon electrode. Acta Chim. Slov. 2007, 54, 68-73.

46. Zitka, O.; Huska, D.; Krizkova, S.; Adam, V.; Chavis, G.J.; Trnkova, L.; Horna, A.; Hubalek, J.; Kizek, R. An investigation of glutathione-platinum(II) interactions by means of the flow injection analysis using glassy carbon electrode. Sensors 2007, 7, 1256-1270.

47. Fojta, M.; Havran, L.; Billova, S.; Kostecka, P.; Masarik, M.; Kizek, R. Two-surface strategy in electrochemical DNA hybridization assays: Detection of osmium-labeled target DNA at carbon electrodes. Electroanalysis 2003, 15, 431-440.

48. Fojta, M.; Havran, L.; Kizek, R.; Billova, S.; Palecek, E. Multiply osmium-labeled reporter probes for electrochemical DNA hybridization assays: detection of trinucleotide repeats. Biosens. Bioelectron. 2004, 20, 985-994.

49. Kizek, R.; Masarik, M.; Kramer, K.J.; Potesil, D.; Bailey, M.; Howard, J.A.; Klejdus, B.; Mikelova, R.; Adam, V.; Trnkova, L.; Jelen, F. An analysis of avidin, biotin and their interaction at attomole levels by voltammetric and chromatographic techniques. Anal. Bioanal. Chem. 2005, 381, 1167-1178.

50. Masarik, M.; Kizek, R.; Kramer, K.J.; Billova, S.; Brazdova, M.; Vacek, J.; Bailey, M.; Jelen, F.; Howard, J.A. Application of avidin-biotin technology and adsorptive transfer stripping squarewave voltammetry for detection of DNA hybridization and avidin in transgenic avidin maize. Anal. Chem. 2003, 75, 2663-2669.

51. Palecek, E.; Kizek, R.; Havran, L.; Billova, S.; Fojta, M. Electrochemical enzyme-linked immunoassay in a DNA hybridization sensor. Anal. Chim. Acta 2002, 469, 73-83.

52. Palecek, E.; Masarik, M.; Kizek, R.; Kuhlmeier, D.; Hassmann, J.; Schulein, J. Sensitive electrochemical determination of unlabeled MutS protein and detection of point mutations in DNA. Anal. Chem. 2004, 76, 5930-5936.

53. Jelen, F.; Kourilova, A.; Pecinka, P.; Palecek, E. Microanalysis of DNA by stripping transfer voltammetry. Bioelectrochemistry 2004, 63, 249-252.

54. Palecek, E. Surface-attached molecular beacons light the way for DNA sequencing. Trends Biotechnol. 2004, 22, 55-58.

55. Palecek, E.; Jelen, F. Electrochemistry of nucleic acids and development of DNA sensors. Crit. Rev. Anal. Chem. 2002, 32, 261-270. 
56. Palecek, E.; Fojta, M. Detecting DNA hybridization and damage. Anal. Chem. 2001, 73, 74A$83 \mathrm{~A}$.

57. Palecek, E. From polarography of DNA to microanalysis with nucleic acid-modified electrodes. Electroanalysis 1996, 8, 7-14.

58. Palecek, E.; Postbieglova, I. Adsorptive Stripping Voltammetry of Biomacromolecules with Transfer of the Adsorbed Layer. J. Electroanal. Chem. 1986, 214, 359-371.

59. Goulding, H.; Jasani, B.; Pereira, H.; Reid, A.; Galea, M.; Bell, J.A.; Elston, C.W.; Robertson, J.F.; Blamey, R.W.; Nicholson, R.A.; Schmid, K.W.; Ellis, I.O. Metallothionein Expression in Human Breast-Cancer. Br. J. Cancer 1995, 72, 968-972.

(C) 2008 by MDPI (http://www.mdpi.org). Reproduction is permitted for noncommercial purposes. 